\title{
WPEYW KLASTRA „GRONO TARGOWE KIELCE” NA ROZWÓJ WOJEWÓDZTWA ŚWIĘTOKRZYSKIEGO
}

\begin{abstract}
Streszczenie
Podstawowym celem artykułu jest prezentacja klastra „Grono Targowe Kielce” (GKT) i wpływu jego działalności na rozwój regionu świętokrzyskiego. W tym celu wykorzystano metodę analizy literatury przedmiotu oraz metodę statystyki opisowej. Na podstawie przeglądu literatury wyjaśniono podstawowe pojęcia związane z klastrami, przedstawiono zasadnicze ich cechy, zalety i wady oraz omówiono zadania i sposób działania klastra GTK.

Jak wynika z analizy, podmioty skupione w klastrze, dzięki wzajemnej współpracy, mogą łatwiej przezwyciężać trudności i kryzysy, niż działając indywidualnie. Zinstytucjonalizowana współpraca podmiotów zrzeszonych w klastrze pozytywnie wpływa na rozwój województwa świętokrzyskiego przez kształtowanie rozwoju turystyki biznesowej, zaliczonej do inteligentnych specjalizacji regionu.
\end{abstract}

Słowa kluczowe: „Grono Targowe Kielce”, branża targowa, województwo świętokrzyskie, rozwój

\section{IMPACT OF “KIELCE TRADE FAIR” CLUSTER ON DEVELOPMENT OF ŚWIĘTOKRZYSKIE VOIVODESHIP}

\section{Summary}

The main goal of this paper is to present the "Kielce Trade Fair" (KTF) cluster and the impact of its activity on the development of Świętokrzyskie Voivodeship. Based on a literature review, the paper explains the basic concepts associated with clusters, presents their characteristics, advantages, and disadvantages. Also presented are the tasks and way of operation of the KTF cluster.

The analysis shows that thanks to mutual cooperation, the entities gathered in the KTF cluster can overcome difficulties and crises more easily than if they acted separately. The institutional cooperation of the entities centred in the cluster has a positive effect on the development of Świętokrzyskie Voivodeship through shaping the development of business tourism, which is one of the smart specialisations of the region.

Key words: Kielce Trade Fair, fair trade industry, Świętokrzyskie Voivodeship, development

DOI: $10.15290 /$ ose.2015.02.74.12

\footnotetext{
${ }^{1}$ Dr Sławomir Pastuszka - Wydział Zarządzania i Administracji, Uniwersytet Jana Kochanowskiego w Kielcach; e-mail: spastuszka@op.pl.
} 


\section{Wstęp}

Koncepcja polityki rozwoju opartej na klastrach (cluster based policy) cieszy się dużą popularnością. Odwołują się do niej politycy i znawcy problematyki rozwoju gospodarczego. Liczne korzyści wynikające dla pojedynczych podmiotów działających w klastrze w powiązaniu z występowaniem korzyści zewnętrznych (externalities) (czyli takich, które nie moga zostać odniesione przez indywidualne podmioty) powoduja że klastry stały się przedmiotem szczególnego zainteresowania władz publicznych różnego szczebla [Krajony Program Reform..., 2013]. Model ten opiera się na współpracy blisko siebie zlokalizowanych przedsiębiorstw z jednej lub pokrewnych branż [Matusiak, 2011]. Przydatność modelu klastra w stosunku do działalności produkcyjnej jest bezdyskusyjna. Podobne korzyści jak przedsiębiorstwa produkcyjne skupione w klasterze czerpią podmioty gospodarcze działające w sektorze usług, w tym usług turystycznych [Kusa, 2008, s. 511-520]. Ścisła współpraca skoncentrowanych terytorialnie podmiotów z sektora usług sprzyja wymianie nowości organizacyjnych, systemowych i marketingowych. Jednak zasadniczym celem podmiotów współpracujących w klastrze usługowym jest oferowanie innowacyjnych, kompleksowych i komplementarnych usług mogących zaspokoić potrzeby klienta.

Mając na uwadze to podejście za podstawowy cel artykułu uznano prezentację klastra „Grono Targowe Kielce” (GKT) i próbę oceny jego wpływu na rozwój województwa świętokrzyskiego. Artykuł składa się z czterech rozdziałów. Na początku przedstawiono teoretyczne rozważania na temat klastrów, następnie omówiono potencjalne efekty działalności klastrów. W trzecim rozdziale przedstawiono uwarunkowania rozwoju klastra „Grono Targowe Kielce”. Piąty rozdział zawiera analizę zmiany wielkości wybranych wskaźników (liczba obiektów turystycznych, liczba miejsc pracy, liczba turystów) dla sektora usług powiązanego z branżą targowa. Na potrzeby analizy wykorzystano dane Głównego Urzędu Statystycznego. Artykuł kończy podsumowanie całości oraz wnioski z podjętej analizy.

\section{Klaster - ujęcie teoretyczne}

Klaster w polskiej literaturze przedmiotu jest traktowany na równi z gronem przemysłowym [Grosse, 2002, s. 44-45]. Pojęcie klastra do literatury przedmiotu po raz pierwszy wprowadził Michael Porter. Według definicji tego, światowej sławy amerykańskiego ekonomisty, klastry to: geograficzne skupisko wrajemnie powiazanych przedsiebiorstw dziatajacych w tych samych lub podobnych branżach oraz wspótpracujacych z nimi wyspecjalizowanych instytucji swiadcracych ustugi dla podmiotón klastra: uniwersytetón, ośrodkón badań naukouych, agencji rozwoju, organizaci handlonych [Porter, 2001, s. 246]. Klaster jest uznawany za przestrzenną formę produkcji zbliżoną do koncepcji Marshalowskich dystryktów przemysłowych (industrial clusters), terytorialnych systemów produkcji i biegunów wzrostu. Jest zatem odmianą zorientowanej na określonym obszarze sieci powiązań firm i różnorodnych instytucji pomocniczych, których działalność często wykracza poza jeden sektor gospodarki (przemysł, usługi), [Pietrzyk, 2002, s. 52-58]. Klastry są tworzone przez przedsiębiorstwa, instytucje naukowe $\mathrm{i}$ władze lokalne, a podejmo- 
wane rozwiązania organizacyjne służą realizacji co najmniej jednej inicjatywy klastrowej. Proces powstania klastra często przedstawia się za pomoca cyklu jego życia. Na początkowym etapie klaster przyjmuje postać embrionalną (embryonic clusters). Istotną rolę na tym etapie rozwoju przypisuje się liderom w branży, a także działaniom rządu i instytucjom wspierającym klastry. Klaster wzrostowy - to następny etap rozwoju polegający na rozszerzeniu klastra o kolejne: przedsiębiorstwa, instytucje otoczenia biznesu i jednostki naukowe. W trzeciej fazie dojrzałości rozwoju klastra maleje liczba uczestników klastra i upowszechnieniu ulegają rozwiązania wykorzystywane przez przedsiębiorstwa. Słabnąca pozycja konkurencyjna klastrów świadczy o tym, że znajduja się one na etapie schyłkowym prowadzonej działalności [Kładź-Postolska, 2013, s. 94-95].

Charakterystycznymi cechami wyróżniającymi klaster od innych form organizacji produkcji są: koncentracja przestrzenna, interakcyjność - powiązania - wspólna trajektoria rozwoju - konkurencja i współpraca. W wyniku współdziałania małych i średnich przedsiębiorstw (SMEs) oraz innych organizacji skupionych w klastrze powstaje efekt synergii, który polega na uzyskiwaniu zwielokrotnionych korzyści dzięki umiejętnemu połączeniu elementów składowych [Rosenfeld, 1996, s. 254-260]. Za sprawą efektu synergii są lepiej wykorzystywane nie tylko zasoby klastra, ale i podmiotów pozostających poza klastrem: dochodzi wówczas do zwiększenia zasięgu rynkowego, poprawy organizacji wewnątrz firm oraz zmniejszenia kosztów działalności biznesowej. Przestrzenna bliskość oraz interakcje między różnymi podmiotami (przedsiębiorstwa, podmioty wspierające rozwój regionalny) działającymi w ramach klastra umożliwiają wzajemne uczenie się oraz absorpcję i generowanie innowacji.

Przepływ wiedzy w ramach klastra jest uzależniony od zaufania między poszczególnymi partnerami klastra. Zaufanie - jako podstawa kapitału społecznego - może być rozwijane przez bezpośrednie kontakty firm (wspólne grupy robocze, seminaria, „wspólna kawa"), które są warunkiem i skutkiem aktywności organizacji klastrowych. Dzięki zaufaniu wzajemne relacje poszczególnych podmiotów w klastrze są mniej sformalizowane, następuje wymiana doświadczeń między nimi czy pogłębienie powiązań kooperacyjnych. Brak zaufania między przedsiębiorcami, a zwłaszcza między przedsiębiorcami a lokalną i regionalną władzą jest podstawową barierą rozwoju klastrów. Przedsiębiorcy nie są zainteresowani szukaniem partnerów do współpracy ani wśród innych firm, ani wśród instytucji otoczenia biznesu. Kolejną bariera jest niski poziom współpracy biznesu z sektorem naukowo-badawczym. Małe i średnie przedsiębiorstwa nie są w stanie ponieść kosztów działalności badawczo-rozwojowej, dlatego przeważnie decydują się na zakup gotowych technologii, urządzeń lub rozwiązań technologicznych. Innym powodem braku współpracy sa odmienne priorytety biznesu i środowiska naukowego. Obie strony wychodzą z założenia, że ich obustronna współpraca będzie nieefektywna. Często są formułowane wzajemne pretensje, $z$ jednej strony o kierunki i jakość edukacji oraz badań naukowych, z drugiej strony o niewielką chłonność rynku pracy czy też rynku rezultatów prac naukowych. Tymczasem nie są to odrębne problemy każdego $\mathrm{z}$ wymienionych środowisk, tylko jeden wspólny problem: umiejętność sprostania nowym wyzwaniom rywalizacji w skali globalnej oraz umiejętności partnerskiej współpracy i pełnienia służebnej roli w stosunku do całej społeczności [Strzelec, 2004, s. 224-225]. 


\section{Potencjalne efekty oddziaływania klastra}

Z wielu analiz wynika, że klastry korzystnie oddziałują na otaczająca je gospodarkę [Final Report..., 2003]. W szczególności wskazuje się na trzy zasadnicze korzyści wynikające $\mathrm{z}$ funkcjonowania klastra $\mathrm{w}$ danym regionie. Po pierwsze, istnienie na danym obszarze silnych i konkurencyjnych klastrów przyczynia się do szybszego rozwoju danego regionu i wzrostu zamożności społeczeństwa. Po drugie, przedsiębiorstwa zlokalizowane w klastrach mają ułatwiony dostęp do specjalistycznych firm i podmiotów. Po trzecie, firmy działające w klastrach są bardziej innowacyjne, co jest konsekwencją bliższej współpracy z zapleczem naukowo-badawczym oraz występowania silnej presji konkurencyjnej (ze strony innych firm z klastra) niejako „wymuszającej” wprowadzanie nowych rozwiązań [Wykorzystanie koncepïi klastrów..., 2009, s. 7]. Kluczową zaletą klastrów jest to, że w pozytywny sposób wpływają na tworzenie kultury innowacyjności i przedsiębiorczości, są atrakcyjnym miejscem lokalizacji dla bezpośrednich inwestycji zagranicznych oraz atrakcyjnym rynkiem pracy przyciagającym wykwalifikowanych pracowników [Innobarometer on cluster's role in facilitating innovation in Europe, 2006; Götz, 2012]. Wprawdzie wszystkie przedsiębiorstwa działające w klastrze osiagają korzyści, to jednak większą korzyść mogą odnieść mniejsze przedsiębiorstwa, którym w przeciwieństwie do podmiotów dużych (międzynarodowych korporacji) wygodniej jest konkurować i współpracować w grupie. Funkcjonowanie klastrów wyzwala efekt dodatkowy (efekt współpracy i rywalizacji), czego nie ma, gdy przedsiębiorstwo działa samodzielnie. Oznacza to, że wzajemnie powiązane przedsiębiorstwa, instytucje i organizacje stanowią większą wartość dla regionalnej gospodarki niż suma tych podmiotów funkcjonujących osobno.

Dany klaster jest tym bardziej konkurencyjny, im ma lepiej rozwinięte relacje międzyorganizacyjne i większe są efekty przenikania wiedzy (naukowej, technologicznej, praktycznej - nieskodyfikowanej), (spillover effects) [Gorynia, Jankowska, 2007, s. 1-18]. Szczególną rolę w nawiązaniu i rozwijaniu kontaktów, relacji i wspólpracy między poszczególnymi przedsiębiorstwami w ramach klastra wypełniaja pracownicy tych firm. Jak słusznie zwrócił uwagę zespół badaczy pod kierunkiem Zbigniewa Olesińskiego: zawsze relacje to jakaś myśl lub driałanie cztonka jednej organizaci w stosunku do čztonka drugiej organizacji. Może to być obserwowanie danej organizacij chociażby przez plot, ale też może to być nawet przypadkowe, ale swiadome zbieranie informaci o funkcjonowaniu danej organizacii, jej produktón. Szregeólnie, gdy wiedza ta jest praydatna i uy korrysstywana w nowej organizaçi [Oleśnicki, 2008, s. 7].

Dostępne przykłady wskazuja, że dzięki klastrom wiele europejskich regionów było zdolnych do wykorzystania swojego potencjału w konkretnych branżach, np. usług finansowych (Londyn), petrochemii (Antwerpia), kwiatów (Holandia), biofarmacji (region graniczny Dania-Szwecja), [Wykorsystanie koncepcji klastrów..., s. 7]. Regiony $\mathrm{z}$ większym udziałem zatrudnienia w branżach należących do silnych klastrów odnotowują wyższy poziom dobrobytu. Uznanie pozytywnego wpływu klastrów na rozwój gospodarczy w konsekwencji prowadzi do uwzględnienia w celach polityki rozwoju regionalnego promowania tego typu struktur ekonomiczno-społecznych. Należy jednak podkreślić, iż sama odgórna interwencja władz publicznych nie zastąpi mechaniz- 
mów rynkowych kształtujących przesłanki dla rozwoju danego grona na określonym obszarze. Oznacza to, iż wspieranie rozwoju gron jest uzasadnione tam, gdzie występują ich „zalążki” (skupiska podmiotów, w szczególności przedsiębiorstw związanych z wytwarzaniem i dostarczaniem określonych rodzajów produktów czy usług, pomiędzy którymi zaczynają występować relacje współpracy), [Plawgo, 2007, s. 7-9]. Prawidłowa identyfikacja przyszłych gron decyduje o korzyściach płynących ze świadomego wspierania ich funkcjonowania.

Z drugiej strony nie można pominąć negatywnych aspektów funkcjonowania klastrów. Po pierwsze, pojawia się zagrożenie, że klastry moga przerodzić się w określonych warunkach w zmowy kartelowe, dyktujące klientom wyższe ceny. Zbyt duża koncentracja niektórych gałęzi gospodarki może zarówno zniechęcać innych potencjalnych inwestorów z branż odmiennych, jak i wpływać na pogorszenie środowiska naturalnego. Podporządkowanie kierunków kształcenia potrzebom klastra, w sytuacji wystąpienia problemów w klastrze, może spowodować wysokie bezrobocie o charakterze strukturalnym, trudne do zmniejszenia [Kierunki i polityka..., 2009, s. 7].

\section{Uwarunkowania rozwoju „Grona Targowego Kielce” (GTK)}

Klaster „Grono Targowe Kielce” został utworzony w Kielcach w 2008 roku. Powołanie GTK zostało poprzedzone analizą uwarunkowań lokalnych i regionalnych na podstawie dokumentów strategicznych miasta Kielce i województwa świętokrzyskiego, która pozwoliła na zidentyfikowanie mocnych stron miasta i regionu, będących szansą dalszego rozwoju, jak też słabych, które są istotną barierę w rozwoju wielu branż gospodarki miasta Kielce i jego okolic (powiatu kieleckiego), [Strategia rozpoju Kregu Branzৃa Tangowo-Kongresowa w województnvie śnietokerysskim..., 2012; Koncepgja utworzenia i driatalności klastra ustugowego „Grono Targowe Kielce”, 2006]. Klaster zrzesza 78 firm i instytucji z otoczenia obsługi imprez wystawienniczych odbywających się w Targach Kielce. Podmioty gospodarcze, funkcjonujące w klastrze, tworzą zakres usług doradczych, wystawienniczych, poligraficznych, szkoleniowych, promocyjnych, hotelarskich, gastronomicznych, transportowych, a także działajacych w sferze: kultury, sportu i promocji. Stanowia zatem niezbędne zaplecze obsługi imprez targowo-konferencyjnych. Ważnym uzupełnieniem klastra sa podmioty z otoczenia biznesu, takie jak: banki, firmy doradztwa biznesowego itp., obejmując część składową klastra lub też działając w silnym związku dzięki odpowiednim umowom czy porozumieniom. Podstawowym źródłem finansowania działalności klastra są składki członkowskie, GTK pozyskuje także fundusze Unii Europejskiej na realizację własnych projektów.

Celem powołania klastra GTK jest podniesienie konkurencyjności przedsiębiorstw działajacych w obszarze organizacji i obsługi imprez targowo-kongresowych oraz usług towarzyszących przez poszerzenie skali i zakresu świadczonych przez nie usług. Podstawowym zadaniem klastra jest reprezentacja interesów gospodarczych członków klastra. Kolejnymi zadaniami sa: organizowanie pomocy członkom klastra w rozwiązywaniu problemów ekonomicznych, organizacyjnych i prawnych dotyczących prowadzenia działalności gospodarczej, ułatwianie przepływu informacji i doświadczeń 
zarówno między firmami z branż pokrewnych, jak i instytucjami edukacyjnymi oraz prowadzenie działalności promocyjnej na rzecz klastra targowo-kongresowo-usługowego.

\section{Struktura klastra usługowego GTK}

RYSUNEK 1.
Działalność wydawnicza
Hotele i gastronomia
Wydawnictwa i poligrafia

IT

Klaster Usługowy GTK

Consulting

Działalność szkoleniowa

Promocja i reklama

Transport

Turystyka

Źródło: [Strategia rožwoju Kreggu ..., 2012, s. 8].

Platformą łączącą działalność firm zainteresowanych powołaniem klastra jest działalność targowo-wystawiennicza Targów Kieleckich, trzeciego ośrodka wystawienniczego w Europie Środkowo-Wschodniej (po Poznaniu i Brnie). Targi Kielce dysponują drugą pod względem wielkości w kraju nowoczesną infrastrukturą konferencyjną i wystawowa, wyposażoną w instalację wodną i elektryczna. Internet, specjalistyczne usługi teleinformatyczne. O wielkości tego ośrodka targowego decyduje wiele czynników: powierzchnia targowa $\left(90000 \mathrm{~m}^{2}\right.$ ), ilość (70) organizowanych imprez targowych (m.in.: znany na całym świecie Międzynarodowy Salon Przemysłu Obronnego - trzecie targi przemysłu obronnego w Europie, PLASTPOL - największe w Europie Centralnej targi przetwórstwa tworzyw sztucznych, Międzynarodowe Targi Budownictwa Drogowego AUTOSTRADA-POLSKA, SACROEXPO - największe w Europie targi sakralne oraz AGROTECH - najchętniej odwiedzane targi rolnicze), liczba (614) i wielkość wystawców, liczba zwiedzających (215 736), wielkość wynajętej powierzchni wystawienniczej $\left(180070 \mathrm{~m}^{2}\right)$ [Dokument elektroniczny, tryb dostępu: http://www.targikielce.pl/index. $\mathrm{html}$ ?k=main\&s=informacje, data wejścia: 05.05.2015]. Równolegle $\mathrm{z}$ imprezami targowymi są organizowane: liczne specjalistyczne konferencje, kongresy, spotkania firmowe, imprezy kulturalne i sportowe.

Wiodąca rola Targów Kielce determinuje podstawowy obszar działalności klastra, który dotyczy usług mających na celu przyciągnięcie i obsługę turysty biznesowego. Założono, że klaster będzie przynosił korzyści nie tylko jego bezpośrednim uczestnikom, ale wygeneruje szereg pozytywnych efektów zewnętrznych dla otoczenia i wpłynie pozytywnie na rozwój regionalny. Przyczyni się do podniesienia konkurencyjności przedsiębiorstw działających w obszarze organizacji i obsługi imprez targowo-kongresowych: chodzi o firmy świadczące usługi hotelarskie, gastronomiczne, doradcze, szkoleniowe, promocyjne, transportowe, poligraficzne oraz w zakresie odnowy biologicznej [Strategia rогуоји Kregu..., 2012, s. 8]. 
TABELA 1.

Potencjał rozwojowy różnych branż w kontekście specjalizacji targowokongresowej w województwie świętokrzyskim

\begin{tabular}{|l|c|c|c|}
\hline \multicolumn{1}{|c|}{$\begin{array}{c}\text { Wyszczególnienie } \\
\text { usług }\end{array}$} & Lańcuch dostaw & $\begin{array}{c}\text { Komplementar- } \\
\text { ność }\end{array}$ & $\begin{array}{c}\text { Związki } \\
\text { lokalizacyjne }\end{array}$ \\
\hline Wystawiennicze & $\mathrm{x}$ & $\mathrm{X}$ & $\mathrm{x}$ \\
Konferencyjno-kongresowe & $\mathrm{x}$ & $\mathrm{X}$ & $\mathrm{x}$ \\
Noclegowe & $\mathrm{x}$ & $\mathrm{X}$ & $\mathrm{x}$ \\
Gastronomiczne & $\mathrm{x}$ & $\mathrm{X}$ & $\mathrm{x}$ \\
SPA\&Welles & $\mathrm{x}$ & $\mathrm{X}$ & $\mathrm{x}$ \\
Brokerskie & $\mathrm{x}$ & $\mathrm{X}$ & $\mathrm{x}$ \\
Reklamowe i promocyjne & $\mathrm{x}$ & $\mathrm{X}$ & \\
Poligraficzne & $\mathrm{x}$ & $\mathrm{X}$ & $\mathrm{x}$ \\
Szkoleniowe i doradcze & $\mathrm{x}$ & $\mathrm{X}$ & \\
\hline
\end{tabular}

x- oznacza potencjalne oddziaływanie pozytywne specjalizacji BTK na dany rodzaj usług.

Źródło: [Innowacyjne specjalizacje..., 2010, s. 26].

Przyjęto, że wyznaczone cele klastra GTK będą realizowane m.in. przez takie działania, jak: realizacja projektów współfinansowanych z unijnych środków pomocowych nakierowanych na promocję przedsiębiorczości, rozwój współpracy sieciowej wewnątrz i na zewnątrz klastra; doradztwo prawne, ekonomiczne, organizacyjne oraz wykonywanie ekspertyz i badań marketingowych; tworzenie i prowadzenie własnych systemów informacji gospodarczej oraz współpraca w tym obszarze z innymi podmiotami prowadzącymi działalność gospodarcza; organizowanie spotkań integrujących środowisko członków klastra; prowadzenie działalności wydawniczej; współpraca i wymiana doświadczeń z ośrodkami oświatowo-naukowymi oraz organizacjami samorządu gospodarczego, organizacjami pracodawców i innymi organizacjami wspierającymi przedsiębiorców; pozyskiwanie inwestorów zagranicznych dla działań biznesowych klastra.

\section{Rozwój sektora usług w województwie świętokrzyskim powiązanego $\mathrm{z}$ branżą targową}

Działalność ośrodka targowego w Kielcach ma duży wpływ na rozwój infrastruktury hotelowej i gastronomicznej, co znajduje potwierdzenie w wielkościach statystycznych. Z danych Głownego Urzędu Statystycznego wynika, że w okresie 20082012 w regionie świętokrzyskim odnotowano wyraźny rozwój bazy noclegowej, sportowo-rekreacyjnej, gastronomii i usług SPA\&Wellnees. Najwyższy wzrost ilościowy obiektów turystycznych nastapił w grupie moteli i hoteli (wzrost odpowiednio o 100\% i o $78 \%$ ) oraz restauracji (wzrost o 53\%). Nowe hotele charakteryzują się wysokim standardem, po raz pierwszy hotele prestiżowe wybudowały przedsiębiorstwa hotelar- 
skie (np.: Best Western, Orbis \& Accor Hotels, Qubus) oraz hotel pięciogwiazdkowy (Odyssey ClubHotel Wellness \& Spa). Z reguły są one wyposażone w infrastrukturę kongresową i rekreacyjno-sportowa. W 2012 roku hotele w województwie dysponowały: 9 basenami krytymi, 20 siłowniami, 17 kortami tenisowymi, 30 boiskami do siatkówki lub koszykówki, 2 pomieszczeniami do mini golfa, 35 pomieszczeniami ze stołem do bilarda, 31 saunami i 4 solariami.

TABELA 2.

Obiekty noclegowe i placówki gastronomiczne w województwie świętokrzyskim

\begin{tabular}{|l|c|c|c|}
\hline $\begin{array}{c}\text { Obiekty noclegowe i placówki } \\
\text { gastronomiczne }\end{array}$ & $\begin{array}{c}\mathbf{2 0 0 8} \\
\text { (szt.) }\end{array}$ & $\begin{array}{c}\mathbf{2 0 1 2} \\
\text { (szt.) }\end{array}$ & $\begin{array}{c}\text { Wzrost/spadek w latach 2008- } \\
\mathbf{2 0 1 2}(\mathbf{~ w ~ \% ) ~}\end{array}$ \\
\hline Hotele & 41 & 73 & 78 \\
Motele & 6 & 12 & 100 \\
Pensjonaty & 6 & 7 & 17 \\
Restauracje & 58 & 89 & 53 \\
\hline
\end{tabular}

Źródło: opracowanie własne na podstawie danych Banku Danych Lokalnych Głównego Urzędu Statystycznego.

TABELA 3.

Pracujący (faktyczne miejsca pracy) w sektorze usług powiązanych z branżą targowo-kongresową w województwie świętokrzyskim

\begin{tabular}{|l|c|c|c|}
\hline \multicolumn{1}{|c|}{ Branże } & $\begin{array}{c}\text { Liczba osób } \\
\text { pracujących } \\
\text { w 2009 roku }\end{array}$ & $\begin{array}{c}\text { Liczba osób } \\
\text { pracujących } \\
\text { w 2012 roku }\end{array}$ & $\begin{array}{c}\text { Wzrost/spadek } \\
\text { w latach w 2008- } \\
\text { 2012 (w \%) }\end{array}$ \\
\hline $\begin{array}{l}\text { Handel } \\
\text { Transport, naprawa pojaz- } \\
\text { dów }\end{array}$ & 59313 & 57529 & $-3,0$ \\
$\begin{array}{l}\text { Zakwaterowanie i gastro- } \\
\text { nomia }\end{array}$ & 5264 & 19492 & $-0,3$ \\
$\begin{array}{l}\text { Informacja i komunikacja } \\
\begin{array}{l}\text { Działalność związana z: } \\
\text { kultura, rozrywką i rekre- } \\
\text { acją }\end{array}\end{array}$ & 2874 & 5249 & $-0,3$ \\
$\begin{array}{l}\text { Pozostała działalność } \\
\text { usługowa }\end{array}$ & 3753 & 4099 & $-2,8$ \\
\hline
\end{tabular}

Źródło: opracowanie własne na podstawie danych Banku Danych Lokalnych Głównego Urzędu Statystycznego.

Niewątpliwie rozwój bazy hotelarsko-gastronomicznej w regionie świętokrzyskim w latach 2008-2012 przyczynił się do stworzenia nowych miejsc pracy. Niestety, nie znajduje to potwierdzenia w wielkościach statystycznych dotyczących zatrudnienia 
w hotelach i gastronomii. Może na ten stan p wływ mogło wywrzeć wiele czynników: osłabienie gospodarki kraju, a zwłaszcza województwa [Wstepne sz̧acunki PKB wedtug wojewódz̧tw..., 2015]. oraz zmiany form zatrudnienia w sektorze turystyki z tradycyjnej umowy o pracę m.in. na umowy cywilnoprawne. Poza tym, badania wykazują iż dążąc do minimalizacji kosztów, osoby zatrudnione w branży hotelowej i gastronomicznej często nie są zgłaszane do ewidencji pracujących [Metodologia badań szarej strefy ..., 2005; Obraz. polskiego rynku pracy w aynikach V edygi badan BKL, 2015]. Wyraźnie wzrosło zatrudnienie w przedsiębiorstwach prowadzących działalność związaną z: kultura, rozrywką i rekreacja (o 9,2\%), co może mieć związek z organizacja: targów, kongresów, imprez kulturalnych, rozrywkowych i rekreacyjnych.

Zaprezentowane zmiany zatrudnienia w wybranych branżach odnotowały podmioty działające głównie w Kielcach i powiecie kieleckim. Przy ogólnym zmniejszeniu liczby pracujących na 1000 ludności w województwie świętokrzyskim, w Kielcach i w powiecie kieleckim stwierdzono wzrost (tabela 4.).

TABELA 4. Liczba osób pracujących na 1000 ludności w województwie świętokrzyskim

\begin{tabular}{|l|c|c|c|}
\hline \multicolumn{1}{|c|}{ Wyszczególnienie } & $\mathbf{2 0 0 8}$ & $\mathbf{2 0 1 0}$ & $\mathbf{2 0 1 2}$ \\
\hline województwo świętokrzyskie & 182 & 182 & 180 \\
powiat miasta Kielce & 354 & 368 & 367 \\
powiat kielecki & 96 & 98 & 99 \\
\hline
\end{tabular}

Źródło: opracowanie własne na podstawie danych Banku Danych Lokalnych Głównego Urzędu Statystycznego.

TABELA 5.

Noclegi udzielone w turystycznych obiektach noclegowych w Polsce i w województwie świętokrzyskim w latach 2008 i 2012

\begin{tabular}{|c|c|c|c|c|c|c|c|c|c|}
\hline \multirow{2}{*}{$\begin{array}{l}\text { Wyszcze- } \\
\text { gólnienie }\end{array}$} & \multicolumn{3}{|c|}{ Ogółem } & \multicolumn{3}{|c|}{ Turyści krajowi } & \multicolumn{3}{|c|}{ Turyści zagraniczni } \\
\hline & $\begin{array}{l}2008 \\
\text { (tys.) }\end{array}$ & $\begin{array}{l}2012 \\
\text { (tys.) }\end{array}$ & $\begin{array}{c}\text { Wzrost/ } \\
\text { spadek } \\
\text { w latach } \\
2008- \\
2012 \\
\text { wyrażo- } \\
\text { ny w \% }\end{array}$ & $\begin{array}{l}2008 \\
\text { (tys.) }\end{array}$ & $\begin{array}{l}2012 \\
\text { (tys.) }\end{array}$ & $\begin{array}{c}\text { Wzrost/ } \\
\text { spadek } \\
\text { w latach } \\
2008- \\
2012 \\
\text { wyrażo- } \\
\text { ny w \% }\end{array}$ & $\begin{array}{l}2008 \\
\text { (tys.) }\end{array}$ & $\begin{array}{l}2012 \\
\text { (tys.) }\end{array}$ & $\begin{array}{c}\text { Wzrost/ } \\
\text { spadek } \\
\text { w latach } \\
2008- \\
2012 \\
\text { wyrażo- } \\
\text { ny w \% }\end{array}$ \\
\hline Polska & 56645,5 & 65157,9 & 15,0 & 46472,3 & 53281,3 & 14,6 & 10173,2 & 11876,6 & 16,7 \\
\hline $\begin{array}{l}\text { święto- } \\
\text { krzyskie }\end{array}$ & 1072,5 & 1347,5 & 25,6 & 1008,3 & 1283,5 & 27,3 & 64,2 & 64,0 & $-1,0$ \\
\hline
\end{tabular}

Źródło: [Turystyka w 2008 roku, 2009; Turystyka w 2012 roku, 2013].

Poprawie ilościowej i jakościowej infrastruktury turystycznych obiektów noclegowych w województwie świętokrzyskim towarzyszył wzrost liczby noclegów udzielonych w latach 2008-2012 turystom krajowym (wzrost o ponad 27\%). W tym okresie 
nieznacznie zmniejszyła się liczba noclegów udzielonych turystom zagranicznym, przy czym do roku 2011 obserwowano coroczny wzrost ich liczby, a w 2012 - spory spadek. Wzrost łącznej liczby udzielonych noclegów w województwie świętokrzyskim jest zbieżny ze zwiększeniem o 27,4\% liczby osób zwiedzających imprezy wystawiennicze w Targach Kielce, z 169367 w 2009 roku do 215736 w 2012 roku (dane Centrum Kongresowego Targi Kielce).

\section{Podsumowanie}

Klaster Grono Targowe Kielce jest wyrazem zapotrzebowania na tworzenie zinstytucjonalizowanej sieci współpracy między podmiotami działającymi w branży targowokongresowej na terenie Kielc i województwa świętokrzyskiego. Współpraca ta przyczynia się do wzmocnienia powiązań między przedsiębiorstwami obejmującymi klaster i otoczeniem instytucjonalnym - szkołami wyższymi, jednostkami naukowo-badawczymi, instytucjami wspomagania biznesu oraz administracja publiczna, co inspiruje wiele różnorodnych inicjatyw, powoduje zwiększanie oferty i podnoszenie standardu usług dla wymagających gości targowych. Wpływa także na rozwój i komplementarność obiektów infrastruktury turystycznej w województwie świętokrzyskim. Przyczynia się do tworzenia specjalizacji w kształceniu studentów na kieleckich uczelniach. Podmioty działające w klastrze GTK mogą łatwiej przezwyciężać różne trudności i kryzysy, niż działając indywidualnie. Wspólpraca uczestników klastra zwiększa atrakcyjność województwa świętokrzyskiego dla turystów i poprawia jego ogólny wizerunek.

Podsumowując, należy stwierdzić bezdyskusyjnie, że klaster GTK pozytywnie wpływa na rozwój województwa świętokrzyskiego dzięki przyśpieszonemu kształtowaniu nowej gałęzi gospodarki w regionie, jaką jest turystyka, dotąd głównie turystyka zdrowotna, a obecnie również biznesowa. Przy ogólnej atrakcyjności historycznej i krajobrazowej województwa świętokrzyskiego, wzmocnionej działalnością targowo-kongresową i uzdrowiskowa, turystyka ma szansę odgrywać istotną rolę w gospodarce regionu. Właśnie dzięki temu znalazła się ona wśród tzw. inteligentnych specjalizacji Regionalnej Strategii Innowacji i jest traktowana jako ważny stymulator rozwoju gospodarki opartej na wiedzy [Strategia Badań i Innowacyjności (RIS3)..., 2014, s. 31-32]. W ten sposób uzyskała oficjalne wsparcie władz samorządowych i miejscowego środowiska naukowego.

\section{Literatura}

Bank Danych Lokalnych, Główny Urząd Statystyczny, dokument elektroniczny, tryb dostępu: [stat.gov.pl/bdl/].

Final Report of the Expert Group on Enterprise Clusters and Networks 2003, European Commission, Enterprise Directorate-General, Brussels.

Gorynia M., Jankowska B. 2007 Wphyw klasterów na konkurencyjność $i$ internacjonalizacje przedsiebiorstw, „Gospodarka Narodowa”, nr 7-8. 
Götz M. 2012 Atrakcyjność klastra dla lokalizacji bezpośrednich inwestygi zagranicznych, Instytut Zachodni, Poznań.

Grosse T.G. 2002 Przeglad koncepiji teoretycznych rozwoju regionalnego, „Studia Regionalne i Lokalne", nr 1(8).

Innobarometer on cluster's role in facilitating innovation in Europe. Analytical Report 2006, European Commission, Eurobarometer.

Innowacyjne specjalizacje wojewódz̨twa świętokrayyskiego 2010, GEOPROFIT, Warszawa. Innowacje i transfer technologii. Stownik Pojeć 2011, K. B. Matusiak (red.), PARP, Warszawa. Kierunki i polityka rozpoju klastrów w Polsce 2009, Ministerstwo Gospodarki, Warszawa.

Kładź-Postolska K. 2013 Wspótpraca w klastrach w różnych fazach ich cyklu syccia, „Gospodarka Narodowa", nr 11-12.

Koncepcja utworzenia i dziatalności klastra ustugowego „Grono Targowe Kielce” 2006, EPRD Biuro Polityki Gospodarczej i Rozwoju Regionalnego, Kielce.

Krajouy Program Reform. Europa 2020. Aktualizacja 2012/2013 2013, Ministerstwo Gospodarki, Warszawa.

Kusa R. 2008 Uwarunkowania rozwoju klastrón turystycznych, [w:] Zarzadzanie organizacjami w gospodarce opartej na wiedzy. Kluczowe relacje gospodarki opartej na wiedsy, B. Godziszewski (red.),TNOiK, Torun.

Metodologia badań szarej strefy na rynku ustug turystycznych 2005, Instytut Koniunktur i Cen Handlu Zagranicznego, Warszawa.

Obraz.polskiego rynku pracy w mynikach V edygi badań Bilansu Kapitatu Ludzkiego. Wyzwania na driś i jutro 28.04.2015 PARP, Warszawa, dokument elektroniczny, tryb dostępu: [http://bkl.parp.gov.pl/program-konferencji2015/, data wejścia: 07.05.2015].

Olesiński Z. 2008 Strategia rozwoju klastrów w województwie śnietokersyskim, Centrum Rozwoju Klastrów Świętokrzyskich, Świętokrzyska Agencja Rozwoju Regionalnego, Kielce.

Pietrzyk I. 2002 Polityka regionalna Unii Europejskiej i regiony w państwach członkowskich, Wydawnictwo Naukowe PWN, Warszawa.

Porter M. 2001 Porter o konkurencji, Polskie Wydawnictwo Ekonomiczne, Warszawa. Prognoza ludności na 2014-2050 2014, GUS, Warszawa.

Rosenfeld S.A. 1996 Does cooperation enhance competitiveness? Assessing the impact of interfirm collaboration, „Research Policy”, no. 25.

Strzelec J. 2004 Regionalna strategia innowacji województwa swietokrayskiego, [w:] Dylematy polskiej polityki spoteczno-gospodarczej, P. Bury (red.),Wydawnictwo Akademii Świętokrzyskiej, Kielce.

Strategia rozwoju Kregu Branża Targowo-Kongresowa w województwie śmietokrayskim. Diagnoza potencjatu konkurencyjności specjalizacii Branìy Targowo-kongresowej (BTK) w województwie swietokrayskim, 2012, Kielce.

Rozwoój struktur klastrowych w Polsce W schodniej 2007, B. Plawgo (red.), Raport Ministerstwa Rozwoju Regionalnego, Warszawa.

Strategia Badań i Innowacyjności (RIS3). Od absorbcji do rezultatón - jak pobudzić potencjat województwa świętokrayyskiego 2014-2020+, 2014, Kielce.

Turystyka w 2008 roku 2009, GUS, Warszawa.

Turystyka w 2012 roku 2013, GUS, Warszawa. 
Wstepne szacunki PKB wedtug wojewódžtw w 2013 roku, 2015, GUS, Urząd Statystyczny w Katowicach.

Wykorsystanie koncepcji klastrón dla ksztaltowania polityki innowacyjnej i technologicznej państwa. Rekomendacje dla polityki stymulowania rozwoju klastrón w Polsce 2009, Instytut Badań nad Gospodarką Rynkową w Polsce, Gdańsk. 